\section{A book that rocked the Victorian world}

\author{
Victorian Sensation: The \\ Extraordinary Publication, \\ Reception and Secret Authorship \\ of Vestiges of the Natural History \\ of Creation \\ by James A. Secord \\ University of Chicago Press: 2001. 581 pp.

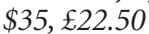

\section{David Oldroyd}

Traditionally, historians of science have studied what scientists have thought and how they generated ideas, as well as the social, economic and political implications of science. Among geo-historians, controversies have attracted particular attention: in his Controversy in Victorian Geology (Princeton, 1986), James Secord wrote the definitive account of the contest between Adam Sedgwick and Roderick Murchison about the Cambrian-Silurian boundary. Now Secord, American by birth but long immersed in British culture - he is Reader in History and Philosophy of Science at Cambridge - re-orients the task of science historians in what will become another definitive book. He asks not so much how Robert Chambers's Vestiges was produced as how it was received, by whom and where. It is a grand but daunting undertaking.

Secord makes the remarkable claim that his book is "the most comprehensive analysis of the reading of any book other than the Bible ever undertaken". I'm not qualified to judge the truth of this assertion, but certainly it is plausible. Immense pains have been taken to set the scene for the publication of the book and to describe, through exhaustive historical research, how it was distributed and sold, and most particularly how it was read - by whom, why, and with what effects on different readers. Thereby the author constructs a remarkably intricate picture of major features of nineteenth-century British culture. All this is undertaken in a book which, despite its long and complex narrative and argument, is both coherent and agreeably written, besides being adorned with 155 illustrations, mostly unfamiliar.

Vestiges (1844), of course, wasn't just any old book. It was a sensation, and a significant piece of the darwinian jigsaw. The fact that it was published anonymously made it special, although anonymity was commoner then than now: reviews were often unsigned and authors (women particularly) often sheltered behind pseudonyms. Chambers opted for anonymity because his cosmic evolutionism - with spontaneous generation and a gradual 'unfolding' of 'higher' life forms in a 'gestatory' process - was incompatible with the deemed truths of revealed religion and potentially

\title{
The treasures beneath our feet
}

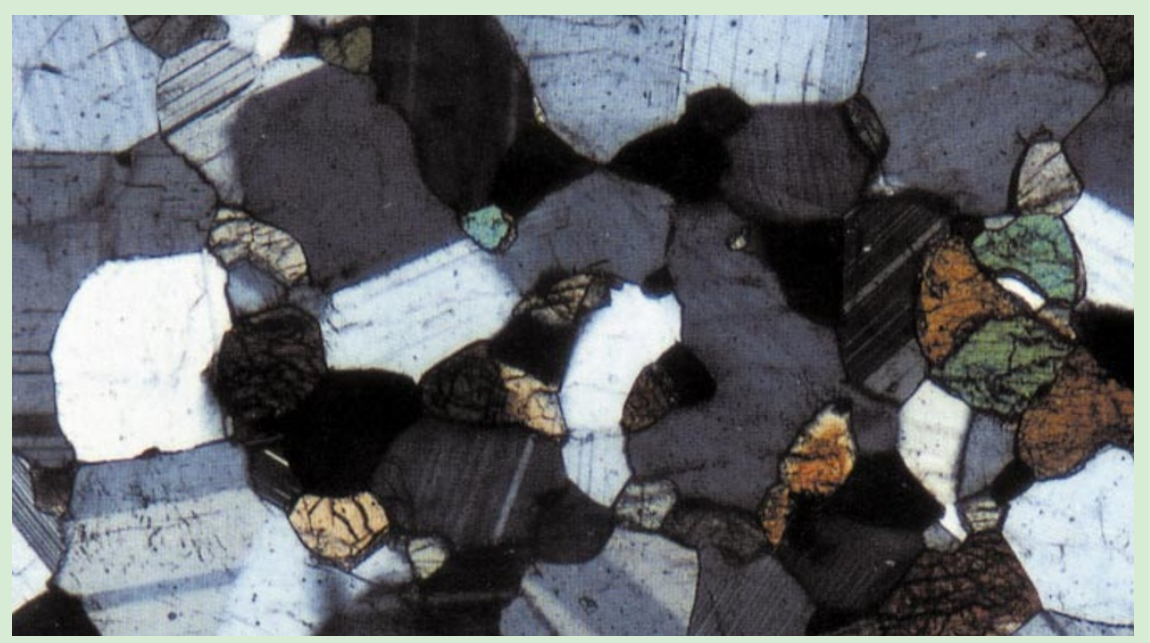

Excellent pictures and straightforward, informative text make Ron Vernon's Beneath our Feet: The Rocks of Planet Earth (Cambridge
University Press, £18.95) almost a coffee-table book for the scientifically literate non-geologist —or anyone who's always curious. subversive of social order. Hence the Edinburgh publisher and amateur scientist wore the cloak of anonymity to protect his business interests, using another firm to issue his book.

Some of Chambers's ideas were implausible, but they included a disturbing actuality: the 'parallelism' between embryonic development, the stratigraphic record, and the principal features of animal classification. These analogies suggested causal connection. This hinted that revealed religion (as then conceived) was deficient - which implied that the social 'cement' might crack if something was not done, and quickly.

The work's anonymity unsettled its reviewers. Were they writing about Charles Lyell, Ada Lovelace, the phrenologist George Combe, the Prince Consort ...? Caution was needed. Adam Sedgwick, however, secure in his Trinity sanctuary, was unrestrained. Writing anonymously in the Edinburgh Review but in his case making sure that his authorship was known - he averred that Vestiges had "annulled all distinction between physical and moral". Pulling rank, he asserted that "[n] o man living, who has not partaken of this kind of [scientific] labour, or ... has not thoroughly mastered the knowledge put before his senses by the labours of other men, has any right to toss out his fantastical crudities before the public, and give himself the airs of a legislator over the material world". Sedgwick had some reason to complain. He had toiled over many mountains, done much original research, mastered many books, fought battles at the Geological Society. His anonymous opponent evidently had not. But Sedgwick was also worried. If Vestiges were correct, his position might be questioned. The comforts of (the) Trinity, or his clerical position at Norwich, might have no moral warrant.

These matters are relatively well known.
But Secord pursues them further. He has examined Sedgwick's annotated copy of Vestiges, showing how he scrawled all over it. He ascertains which passages attracted Sedgwick's attention, and how he responded to them. Similarly, Secord shows how the Halifax autodidact, Thomas Hirst, doggedly wrote out extracts from Vestiges, assimilating them with, as Secord puts it, "extraordinary intensity". "Almost no one," he continues, "reads like this any more." True. Books were scarcer items then than now, and everything possible had to be wrung from them by the earnest self-improver.

Of course, Darwin's shadow falls over this. But in his epilogue, Secord argues that it was not just Darwin's work that changed everything, creating a new world-view. For example, although The Origin of Species appeared in 1859 , it was selling fewer copies than Vestiges until the 1880s. Focusing all attention on Darwin obscures rather than clarifies the past. So by concentrating on the production, distribution and reception of Chambers's book and the "network of relations that make up the larger picture", rather than the factors that led him to arrive at his ideas, Secord aims to offer "an experiment in a different kind of history".

Secord's method of enquiry shows that there was not a homogeneity of Victorian thought. People read and responded to Vestiges differently according to their geographical, political, economic or religious circumstances. It wasn't just "Darwin's century", to use the well-known phrase of Loren Eiseley. To show all this coherently and intelligibly, as Secord has done, is no small undertaking. Take a lead from Secord's book: read Victorian Sensation and see what you make of it. David Oldroyd is in the School of Science and Technology Studies, University of New South Wales, Sydney 2052, Australia. 